\title{
PENDEKATAN KETERAMPILAN PROSES SAINS DALAM BENTUK PROYEK KARYA ILMIAH UNTUK MENUMBUHKAN MINAT BELAJAR SISWA
}

\author{
Fajar Adinugraha \\ fadinugraha@yahoo.co.id \\ Universitas Kristen Indonesia
}

\begin{abstract}
ABSTRAK
Tujuan penelitian ini adalah (1) untuk menjelaskan penerapan pendekatan keterampilan proses sains dalam bentuk proyek karya ilmiah, dan (2) untuk mengetahui minat belajar biologi siswa setelah diberi perlakuan proyek karya ilmiah. Metode penelitian menggunaan eksperimen one shot case study. Populasi adalah siswa kelas X SMA Citra Kasih. Sampel adalah siswa kelas X MIPA tahun ajaran 2014/2015 sebanyak 25 siswa. Proyek karya ilmiah merupakan tugas yang diberikan kepada siswa secara berkelompok dan dilakukan secara terbimbing mulai dari penentuan judul, penyusunan proposal, pelaksanaan penelitian, penyusunan laporan penelitian, dan presentasi. Proyek karya ilmiah dapat menumbuhkan minat siswa terhadap pembelajaran Biologi. Hal ini dibuktikan dengan $88 \%$ siswa menyatakan minat terhadap Biologi setelah diberi proyek karya ilmiah.
\end{abstract}

Kata kunci: Keterampilan Sains, Proyek Karya Ilmiah, Minat siswa

\begin{abstract}
The research objectives are (1) to explain the application of scientific skill approach using scientific work project, and (2) to know the students' interest after the respondents was given scientific work project treatment. The research method is experiment with one shot case study. The population is the Grade $X$ students of SMA Citra Kasih Jakarta. The samples are 25 students of Class X MIPA academic year 2014/2015. Scientific work project is a task that is given to students in groups and it is conducted with guide from title determination, proposal preparation, research implementation, research reporting, and presentation. The project of scientific work is able to make students interest in Biology learning. This is proofed by $88 \%$ students who increasing interest in learning Biology after being given a project of scientific work.
\end{abstract}

Keywords: scientific skill, scientific work project, students' interest 
Adinugraha, Pendekatan Keterampilan Proses Sains dalam Bentuk Proyek Karya IImiah untuk Menumbuhkan Minat Belajar Siswa

\section{PENDAHULUAN}

Keterampilan proses sains merupakan salah satu keterampilan yang harus dimiliki oleh siswa peminatan MIPA khususnya Biologi. Pembelajaran biologi tidak dapat lepas dari pendekatan keterampilan proses sains. Menurut Hamalik (2005) dalam Juhji (2016, h. 61), mengatakan bahwa keterampilan proses dalam bidang ilmu pengetahuan alam adalah pengetahuan tentang konsepkonsep dalam prinsip-prinsip yang dapat diperoleh siswa bila siswa tersebut memiliki kemampuan dasar tertentu yaitu keterampilan proses sains.

Menurut Acesta (2014, h. 97), mengatakan bahwa pendekatan keterampilan proses adalah pendekatan pembelajaran yang menekankan pada proses belajar, aktivitas, dan kreativitas peserta didik dalam memperoleh pengetahuan, keterampilan, nilai, dan sikap, serta menerapkan dalam kehidupan sehari-hari. Oleh karena itu, dapat disintesiskan bahwa keterampilan proses sains adalah keterampilan yang harus dimiliki oleh peserta didik sebagai akibat dari proses pembelajaran yang menekankan kegiatan saintifik. Keterampilan proses sains yang dimaksud dalam artikel ini meliputi: 1) mengamati dan menafsirkan pengamatan; 2) memprediksi; 3) menggunakan peralatan dan mengukur; 4) mengajukan pertanyaaan; 5) merumuskan hipotesis; 6) merencanakan penyelidikan/ percobaan; 7) mengintepretasikan; dan 8) berkomunikasi.

Pendekatan keterampilan proses sains ini dapat diterapkan dengan menggunakan model Pembelajaran Berbasis Proyek atau project based learning. Menurut Thomas dalam Wena (2013, h. 144), model Pembelajaran Berbasis Proyek berdasarkan adanya permasalahan yang diungkap dan kegiatan belajar bersifat kolaboratif (berkelompok) yang membuat lingkungan siswa 
menjadi lebih aktif. Dalam model Pembelajaran Berbasis Proyek, siswa lebih ditekankan dalam kegiatan merancang atau mendesain proyek, mulai dari merumuskan proyek, merancang, melaksanakan proyek, dan mengevaluasi hasil. Menurut Adinugraha (2017, h. 442), model Pembelajaran Berbasis Proyek merupakan sebuah model pembelajaran yang memberikan kesempatan guru untuk melibatkan siswa dalam pembuatan proyek tertentu dan dalam jangka waktu tertentu.

Proyek yang dipilih dalam model ini adalah proyek karya ilmiah. Proyek ini dipilih karena pada materi kelas $X$ semester 1 terdapat kompetensi dasar mengenai metode ilmiah. Pada umumnya, materi metode ilmiah ini hanya dijelaskan dengan teori saja sehingga membuat siswa menjadi hanya menghafal tetapi tidak melakukan tahapantahapan metode ilmiah sesuai dengan teori. Selain itu, proyek karya ilmiah ini diharapkan dapat menumbuhkan minat siswa terhadap pembelajaran biologi. Apabila siswa memiliki minat belajar biologi, maka akan mempengaruhi hasil belajar biologi.

Berdasarkan hasil kuesioner yang dibagikan kepada 25 siswa, sekitar 52\% siswa menyatakan minat terhadap pelajaran biologi. Dari 52\% siswa, sekitar 40\% menyukai atau minat belajar biologi karena tidak suka pelajaran menghitung seperti fisika dan kimia, dan sisanya $12 \%$ menyukai atau minat belajar biologi karena memang menyukai topik tentang alam atau binatang.

Dari 25 siswa, sekitar $48 \%$ tidak memiliki minat terhadap pelajaran biologi. Sekitar $36 \%$ siswa menyatakan ketidaksukaan terhadap biologi karena pembelajaran biologi saat SMP sangat membosankan. Siswa lebih banyak mencatat dan menghafal teori. Sekitar $12 \%$ siswa menyatakan tidak menyukai biologi karena memang tidak suka menghafal materi terlalu banyak. 
Adinugraha, Pendekatan Keterampilan Proses Sains dalam Bentuk Proyek Karya IImiah untuk Menumbuhkan Minat Belajar Siswa

Penerapan pembelajaran berbasis berupa proyek karya ilmiah diharapkan membuat siswa tertarik terhadap pembelajaran biologi yang mengutamakan keterampilan proses sains. Pada dasarnya, keterampilan proses sains ini tercantum dalam kegiatan pembelajaran Kurikulum 2013 dengan nama pendekatan saintifik. Proyek karya ilmiah ini diharapkan dapat membuat siswa berpikir untuk memilih topik-topik untuk penelitian sederhana. Topik yang diberikan adalah yang menarik menurut siswa. Hal ini akan membuat siswa menjadi tertantang akan judul proyek karya ilmiah yang dipilih.

Berdasarkan uraian di atas maka artikel ini bertujuan untuk mengetahui:

1) Penerapan pembelajaran proyek karya ilmiah di SMA Citra Kasih Jakarta?

2) Minat belajar Biologi siswa SMA Citra Kasih Jakarta setelah diterapkan model pembelajaran proyek karya ilmiah?

\section{METODOLOGI PENELITIAN \\ Metode \\ Penelitian ini dilaksanakan} dari bulan Oktober 2014-Februari 2015. Pada bulan Oktober 2014 dilakukan observasi. Bulan November 2015-Februari 2015 dilakukan eksperimen penerapan model pembelajaran proyek karya ilmiah. Bulan Februari 2015 dilakukan pengambilan data untuk minat siswa.

Tempat penelitian di SMA Citra Kasih Jakarta tahun akademik 2014/2015. Populasi dalam penelitian ini adalah siswa kelas X SMA Citra Kasih tahun ajaran 2014/2015. Sampel penelitan adalah siswa kelas $X$ MIPA tahun ajaran 2014/2015 sebanyak 25 siswa yang terdiri dari 15 siswa laki-laki dan 10 siswa perempuan. Metode pengambilan sampel dengan purposive random sampling. Jenis penelitian ini adalah pre eksperimental design dengan rancangan the one-shot case 
study. Desain penelitian dapat Data ini diambil dengan cara diilihat pada tabel 1. mendeskripsikan 1) tahapan Pengambilan data dapat pembelajaran dan dijelaskan sebagai berikut. assesment pembelajaran 1. Data penerapan pembelajaran proyek karya ilmiah. dengan penerapan proyek karya ilmiah.

Tabel 1 Desain penelitian

\begin{tabular}{cl}
\hline $\mathbf{X}$ & \multicolumn{1}{c}{$\mathbf{0}$} \\
\hline Treatment of independent variable & $\begin{array}{l}\text { Observation or measurement of } \\
\text { dependent variable }\end{array}$ \\
\hline
\end{tabular}

Keterangan

$\mathrm{X} \quad=$ penerapan proyek karya ilmiah

$\mathrm{O}=$ minat belajar biologi siswa

Tabel 2.

Indikator minat belajar

\begin{tabular}{ll}
\hline No & Indikator \\
\hline 1. & Frekuensi mengikuti pelajaran \\
2. & Keaktifan dalam mengerjakan proyek \\
3. & Ketepatan waktu dalam mengumpulkan proyek \\
4. & Kerapihan dan konsistensi proyek \\
5. & Keaktifan dalam mengikuti pelajaran \\
\hline
\end{tabular}

Tabel 3.

Kategori minat siswa

\begin{tabular}{ll}
\hline Kategori & Rentang \\
\hline Sangat minat & $84 \leq X \leq 100$ \\
Minat & $68 \leq X \leq 83$ \\
Cukup minat & $52 \leq X \leq 67$ \\
Kurang minat & $36 \leq X \leq 51$ \\
Tidak minat & $20 \leq X \leq 35$ \\
\hline
\end{tabular}

2. Data minat belajar biologi.

Data ini diambil dengan menggunakan kuesioner dengan indikator yang disajikan pada tabel 2 .
Kuesioner diberikan setelah penerapan proyek karya ilmiah dilakukan. Kuesioner menggunakan skala 1-5 dengan jumlah 20 butir 
Adinugraha, Pendekatan Keterampilan Proses Sains dalam Bentuk Proyek Karya IImiah untuk Menumbuhkan Minat Belajar Siswa

pernyataan. Selanjutnya, data tersebut ditabulasi dalam excel dan dikategorikan dalam kategori dalam tabel 3 . Selanjutnya, data ditampilkan dalam bentuk diagram batang

\section{HASIL DAN PEMBAHASAN}

\section{Penerapan proyek karya} ilmiah

Penerapan proyek karya ilmiah dilaksanakan selama enam bulan. Proyek ini dilakukan secara kelompok yaitu 2 sampai 3 anggota dalam satu kelompok. Menurut Saptono (2003, hh. 3233), terdapat kelebihan dalam pembelajaran kelompok (kooperatif).

Pertama, terjadinya saling ketergantungan secara positif. Siswa berkelompok, saling bekerja sama dan mereka menyadari bahwa mereka saling membutuhkan satu sama lain. Kedua, terbentuknya tanggung jawab personal. Setiap anggota kelompok akan memiliki rasa tanggungjawab untuk belajar dan mengemukakan pendapatnya sebagai sumbang saran dalam kelompok.
Ketiga, akan terjadinya keseimbangan dan keputusan bersama dalam kelompok. Dalam kelompok tidak hanya seorang atau orang tertentu saja yang berperan melainkan ada keseimbangan antarpersonal dalam kelompok. Keempat, interaksi menyeluruh. Setiap anggota kelompok memiliki tugas masing-masing secara proporsional dan secara simultan mengerjakan tugas atau menjawab pertanyaan. Penerapan proyek karya ilmiah dapat dijelaskan sebagai berikut:

a. Pemilihan topik/ judul

Pemilihan topik diberikan secara bebas kepada siswa. Mengingat ilmu Biologi sangat luas dan berkaitan dengan ilmu lain, siswa bisa memilih topik yang berkaitan dengan pertanian, genetika, lingkungan, botani, kependudukan, energi alternatif dan sebagainya. Pemilihan topik yang dibebaskan kepada siswa ini bertujuan agar siswa tertarik terhadap topik yang siswa pilih. Hal ini membuat siswa menjadi semangat akan 
tugas yang dikerjakan. Pemilihan topik ini diberi tenggat waktu 2 minggu.

b. Pembuatan Proposal.

Pada pertengahan Oktober hingga akhir November 2014, siswa dibimbing oleh guru untuk membuat proposal penelitian. Pembuatan proposal dilakukan di jam pelajaran yang sudah ditentukan sehingga tidak mengganggu dalam proses pembelajaran biologi. Selain itu, pembuatan proposal dilakukan dengan sistem konsultasi di luar jam pelajaran. Pada saat pembuatan proposal, siswa juga bisa berkonsultasi dengan guru atau ahli lain yang memiliki keterkaitan dengan topik yang dipilih. Pada saat konsultasi, siswa membawa kartu konsultasi yang bertujuan untuk memantau perkembangan proposal.

c. Pelaksanaan Penelitian.

Setelah proposal dinyatakan layak, siswa diberi waktu untuk melakukan penelitian selama enam bulan. Dalam pelaksanaan penelitian, guru tetap memantau dan mengarahkan siswa tersebut.
Hal ini mengingat siswa SMA masih belum mengerti prosedur penelitian dengan benar. Penelitian seperti penggunaan hewan untuk eksperimen memang dilarang dalam tugas ini. Hal ini menyangkut kode etik penelitian.

d. Pembuatan Laporan Penelitian Pembuatan laporan penelitian dilakukan apabila data yang dikumpulkan oleh siswa sesuai yang diinginkan. Di dalam pembuatan laporan, siswa tetap terus berkonsultasi dengan guru pembimbing. Hal ini dilakukan agar analisis data, pembahasan dan kesimpulan bisa terjadi sinkronisasi. Pada pertengahan Februari, karya ilmiah dikumpulkan dalam bentuk hardcopy dan softcopy.

e. Pembuatan Power Point.

Pembuatan power point perlu dibimbing agar ketika presentasi power point dapat digunakan secara maksimal.
f. Pelaksanaan Presentasi
Pelaksanaan presentasi dilakukan di akhir Februari hingga pertengahan Maret. Siswa 
Adinugraha, Pendekatan Keterampilan Proses Sains dalam Bentuk Proyek Karya IImiah untuk Menumbuhkan Minat Belajar Siswa

melakukan presentasi di hadapan

guru pembimbing dan siswa.

Durasi presentasi 45 menit (15 menit penyajian, 15 menit komentar audien, dan 15 menit komentar guru pembimbing).

Penerapan proyek karya ilmiah ini ternyata sesuai dengan pendekatan keterampilan proses sains dan pendekatan kurikulum 2013. Hal ini karena di dalam proyek karya ilmiah mengajak siswa berifikir saintifik. Data dapat dilihat pada tabel 4 .

Tabel 4.

Kesesuaian Proyek Karya IImiah dengan Pendekatan Keterampilan Proses dan Pendekatan Saintifik Kurikulum 2013

Pendekatan Saintifik Pendekatan $\quad$ Proyek Karya IImiah Kurikulum 2013

- Mengamati Keterampilan Proses

- Menanya

- Mengamati dan

- Merumuskan menafsirkan pengamatan

- Memprediksi

- Mengajukan pertanyaan

- Merumuskan hipotesis

- Merencanakan eksperimen

- Pengumpulan data (eksperimen)

- Menggunakan peralatan dan mengukur

- Mengintepretasikan

- Mengasosiasikan

- Mengkomunikasikan
- Berkomunikasi masalah dan tujuan penelitian

- Mengajukan hipotesis

- Mensintesiskan tinjauan pustaka

- Merancang penelitian

- Melakukan eksperimen

- Mengumpulkan data

- Analisis data

- Pembahasan analisis data

- Pembuatan laporan

- Presentasi
Berdasarkan tabel 4 di atas, dapat dikatakan bahwa, proyek karya ilmiah memuat unsur-unsur baik yang terdapat pada pendekatan saintifik Kurikulum
2013 maupun pendekatan keterampilan proses. Proyek karya ilmiah merupakan sebuah pengalaman belajar siswa yang meliputi beberapa tahap seperti: 
1) merumuskan masalah; 2) merumuskan tujuan penelitian; 3) mensintesis teori tinjauan pustaka; 4) menyusun hipotesis; 5) merancang percobaan; 6) melaksanakan percobaan/ eksperimen; 7) menganalisis data; 8) melakukan pembahasan terhada analisis data; dan 9) menarik kesimpulan.

Proyek karya ilmiah memiliki kelebihan dan kekurangan. Kelebihan yang dimiliki adalah sebagai berikut.

1. Siswa diajak untuk menuangkan ide ke dalam bentuk tulisan. Siswa menjadi lebih aktif. Hal ini sesuai dengan prinsip pembelajaran biologi yaitu Student Centered Learning.

2. Siswa mampu terlibat dalam 3 kegiatan sekaligus yaitu ranah kognitif (kemampuan berpikir dalam memecahkan sebuah masalah), ranah afektif (sikap individu maupun dalam anggota kelompok), dan ranah psikomotorik (bentuk keterampilan proses sains). Hal ini sesuai dengan prinsip kurikulum 2013 yang mengutamakan sinergi antara kemampuan pengetahuan (kognitif), sikap sosial dan spiritual (afektif), dan keterampilan (psikomotorik).

3. Siswa akan belajar dengan melakukan sesuatu. Siswa tidak hanya menghafal materi saja tapi mengaplikasikan dalam sebuah kegiatan. Hal ini sesuai prinsip pembelajaran Biologi yaitu Learning by doing.

4. Siswa dilatih untuk memecakan masalah. Permasalahan yang dipilih siswa dalam karya ilmiah perlu dicari solusinya sesuai dengan dasar-dasar teori yang relevan. Hal ini sesuai dengan prinsip pembelajaran Biologi yaitu The daily life problem solving. Dengan membiasakan siswa untuk memecahkan masalah, guru secara tidak langsung menyiapkan sumber daya manusia yang berdaya saing tinggi. 
Adinugraha, Pendekatan Keterampilan Proses Sains dalam Bentuk Proyek Karya IImiah untuk Menumbuhkan Minat Belajar Siswa

5. Pembelajaran biologi menjadi pembelajaran yang bermakna (meaningful learning). Kegiatan proyek karya ilmiah ini akan tersimpan di dalam memori siswa dibanding dengan hanya mempelajari teori saja.

6. Pembelajaran akan menjadi menyenangkan.

Siswa melakukan aktivitas sehingga tidak jenuh ketika belajar biologi. Namun, tentunya tetap pada aturan kedisiplinan yang sudah ditetapkan. Hal ini sesuai dengan prinsip pembelajaran biologi yaitu Joyful learning.

7. Menumbuhkan sikap toleransi antar siswa. Sikap toleransi perlu ditanamkan di dalam jiwa siswa. Hal ini mengingat banyak kasus di dalam masa remaja yang terjadi karena tidak ada rasa kerja sama, peduli dan toleransi. Dengan kerja kelompok, sesama anggota harus mampu memahami karakter antar anggota, sehingga mau tidak mau mereka harus bekerja bersama dengan selesainya proyek karya ilmiah.

Kelebihan proyek karya ilmiah ini sesuai dengan hakikat pembelajaran biologi. Menurut Saptono (2003, hh. 2-3). Hakikat pembelajaran biologi antara lain: 1) Biologi sebagai kumpulan pengetahuan; 2) Biologi sebagai proses investigasi; 3) Biologi sebagai kumpulan nilai; 4) Biologi sebagai bagian dari kehidupan sehari-hari.

Proyek karya ilmiah ini memiliki beberapa kelemahan. Kelemahan proyek/ tugas ini adalah sebagai berikut.

1. Waktu yang dibutuhkan siswa untuk mengerjakan tugas ini lama yaitu sekitar 6-8 bulan. Hal ini perlu dilakukan agar dihasilkan karya ilmiah yang berkualitas dan terhindar dari plagiat. Selain itu, siswa SMA belum terbiasa dengan karya ilmiah sehingga mereka agak lama dalam membuatnya. Oleh karena itu, guru cukup memberikan satu proyek ini untuk satu tahun. Hal ini 
karena di dalam proyek ini bisa diambil beberapa aspek nilai. Selain itu, proyek ini bisa dilakukan terintegrasi dengan mata pelajaran lain seperti mata pelajaran Bahasa Indonesia, Fisika, Kimia dan Matematika. Hal ini akan mengurangi beban tugas siswa di sekolah jika dilakukan terintegrasi dengan mata pelajaran lain.

2.

Kurangnya

jam dalam pembelajaran. Pengerjaan tugas seharusnya dilakukan di jam pelajaran. Hal ini tentunya akan membuat waktu pembelajaran menjadi lebih singkat. Guru perlu menyiasati akan hal ini. Oleh karena itu, terkadang ada waktu yang diberikan bagi siswa untuk menyelesaikan proyek tersebut di jam pelajaran dan sisanya dilakukan di luar jam pelajaran. Hal ini dilakukan agar materi pelajaran bisa terselesaikan dengan baik. Guru perlu memiliki manajemen kelas dan waktu yang baik.
3. Guru pembimbing perlu meluangkan waktu lebih untuk membimbing siswa. Pemeriksaan proposal dan laporan penelitian serta konsultasi di luar jam pelajaran akan menyita waktu guru. Oleh karena itu, guru perlu menyiasati hal tersebut.

\section{Minat belajar biologi}

Untuk mengetahui minat belajar, kuesioner minat belajar biologi diberikan kepada responden yaitu 25 siswa kelas $X$ SMA Citra Kasih Jakarta. Kuesioner ini terdiri dari 20 butir pernyataan dengan indikator antara lain: 1) frekuensi mengikuti pelajaran; 2) keaktifan dalam mengerjakan proyek; 3) ketepatan waktu dalam mengumpulkan proyek; 4) kerapihan dan konsistensi proyek; dan 5) keaktifan dalam mengikuti pelajaran. Data tersebut kemudian ditabulasi dalam microsoft excel. Data minat belajar Biologi yang diperoleh disajikan dalam tabel 4 . Selanjutnya, disajikan diagram pada gambar 1 . 
Adinugraha, Pendekatan Keterampilan Proses Sains dalam Bentuk Proyek Karya IImiah untuk Menumbuhkan Minat Belajar Siswa

Berdasarkan data, dapat mampu merumuskan konsep dikatakan bahwa sekitar 88\% melalui kegiatan mengkonstruksi siswa menyatakan minat belajar berdasarkan diskusi dan temuan. Biologi (14 siswa sangat minat Selain itu, siswa merasa yakin dan 8 siswa minat terhadap dan percaya diri terhadap pelajaran biologi). Minat siswa kemampuan yang dimiliki, didorong oleh beberapa faktor, sehingga siswa berani dalam salah satunya adalah pendekatan mengungkapkan pendapat, pembelajaran atau model pertanyaan, dan gagasannya pembelajaran. Siswa termotivasi (Julianto, 2010,h. 11). dalam mengikuti kegiatan pembelajaran karena siswa

\section{Tabel 4}

Data minat belajar biologi setelah diberi perlakuan proyek karya ilmiah

\begin{tabular}{|c|c|}
\hline Kategori & Jumlah \\
\hline Sangat minat & 17 \\
\hline Minat & 5 \\
\hline Cukup minat & 3 \\
\hline Kurang minat & 0 \\
\hline Tidak minat & 0 \\
\hline
\end{tabular}




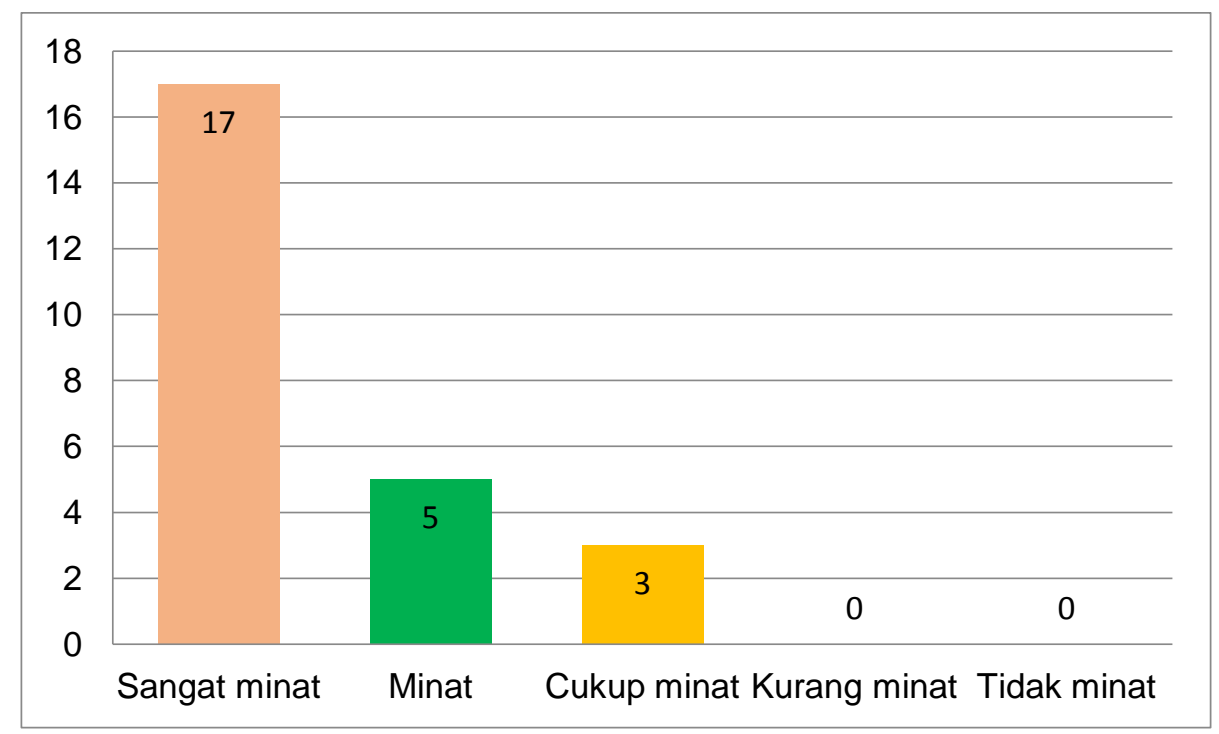

Gambar 1. Diagram batang minat siswa terhadap biologi setelah diberi perlakuan proyek karya ilmiah

Menurut Slameto (2010, h. 180) dalam Yunita (2015, h. 1) mengatakan bahwa minat merupakan ketertarikan siswa terhadap pembelajaran yang muncul akibat pengalaman yang dimiliki.

Minat tidak serta merta tumbuh tetapi minat merupakan akibat dari sesuatu yang membuat siswa tertarik akan sesuatu. Minat dapat mempengaruhi hasil belajar siswa.

Berdasarkan data, dikatakan bahwa terdapat 3 (tiga) siswa yang cukup minat terhadap pembelajaran Biologi. Setelah dilakukan wawancara, 3 (tiga) responden tersebut memang tidak memiliki niatu ntuk masuk jurusan MIPA. Hal ini karena masuknya responden tersebut ke jurusan MIPA karena dorongan dari orang tua.

Berdasarkan hasil penelitian Jirana (2015, h. 92), aspek psikologi termasuk motivasi, perhatian, ketertarikan, bakat menjadi hal yang penting dalam minat belajar. Oleh karena itu, penting bagi stakeholders pendidikan, yaitu sekolah dan keluarga untuk tetap menjaga kondisi psikologis siswa demi tercapainya tujuan belajar siswa. 
Adinugraha, Pendekatan Keterampilan Proses Sains dalam Bentuk Proyek Karya IImiah untuk Menumbuhkan Minat Belajar Siswa

Pemilihan jurusan atau peminatan perlu didiskusikan dengan serius oleh siswa, orangtua dan sekolah, agar siswa memiliki semangat dalam pembelajaran. Bentuk sebuah model pembelajaran atau pendekatan pembelajaran yang tepat akan mampu menumbuhkan minat belajar siswa.

Sebagai seorang guru, seyogyanya mampu memelihara minat siswa. Hal ini seperti dikatakan oleh Nurkacana (1993, h. 230) dalam Susanto (2013, h. 63)sebagai berikut:

1. Setiap guru wajib meningkatkan minat siswa.

2. Guru sebaiknya memelihara minat siswa yang timbul walaupun minat yang timbul sangat kecil.

3. Guru harus mampu mencegah timbulnya minat siswa terhadap hal-hal yang tidak baik.

4. Guru perlu memberikan bimbingan terhadap minat siswa untuk perkembangan lanjutan studi atau pekerjaan

yang sesuai bagi diri siswa.

\section{PENUTUP}

\section{Simpulan}

Berdasarkan dari deskripsi pembahasan di atas, maka dapat disimpulkan sebagai berikut.

1. Proyek karya ilmiah merupakan tugas yang diberikan kepada siswa secara berkelompok dan dilakukan secara terbimbing mulai dari penentuan judul, penyusunan proposal, pelaksanaan penelitian, penyusunan laporan penelitian, dan presentasi.

2. Proyek karya ilmiah dapat menumbuhkan minat siswa terhadap pembelajaran Biologi. Hal ini dibuktikan dengan $88 \%$ siswa menyatakan minat terhadap Biologi setelah diberi proyek karya ilmiah.

\section{Saran}

Berdasarkan simpulan penelitian, maka beberapa saran terkait yang dapat penulis 
sampaikan adalah sebagai berikut.

1. Guru hendaknya memberikan kesempatan kepada siswa untuk menuangkan ide atau daya pikir ilmiah siswa dengan model pembelajaran proyek karya ilmiah.

2. Proyek karya ilmiah dapat dijadikan alternatif untuk mengembangkan bentuk keterampilan proses sains siswa dan sebagai wujud pendekatan saintifik kurikulum 2013.

3. Guru harus memberikan semangat kepada siswa

\section{ACUAN PUSTAKA}

Acesta A. (2014). Penerapan pendekatan keterampilan proses sains untuk meningkatkan hasil belajar siswa dalam pembelajaran IPA. Jurnal IImiah Pendidikan Dasar. 1 (2): 96-106.

Adinugraha F. (2017). Pengaruh model pembelajaran dan efikasi diri terhadap sikap ilmiah siswa sma peminatan mipa. Jurnal Pro-life. 4 (3): 442-455.

Jirana J, Syamsiara N, Nurmiati. (2015). Faktor-faktor yang mempengaruhi kesulitan dan dalam menyelesaikan tugas dan memberikan waktunya untuk hasil karya ilmiah yang baik.

4. Antar sesama guru bidang studi saling bekerjasama untuk proyek karya ilmiah yang terintegrasi.

5. Sekolah harus mau dan mampu memberikan wadah bagi siswa dan guru untuk mengembangkan kreativitas dan inovasi dalam menyusun aktivitas atau kurikulum pembelajaran.

minat belajar mahasiswa jurusan pendidikan biologi universitas sulawesi barat. Jurnal Saintifik. 1 (2): 87-94.

Juhji J. (2016). Peningkatan keterampilan proses sains siswa melalui pendekatan inkuiri terbimbing. Jurnal Penelitian dan Pembelajaran IPA. 2 (1): (58-70).

Julianto T. (2010). Meningkatkan minat belajar biologi menggunakan pembelajaran ctl (contextual teaching and learning) pada siswa di kelas vii-b mts negeri purwokerto. 
Adinugraha, Pendekatan Keterampilan Proses Sains dalam Bentuk Proyek Karya IImiah untuk Menumbuhkan Minat Belajar Siswa

Jurnal Khazanah Pendidikan. 3(1): 11-13.

Saptono S. (2003). Strategi belajar mengajar biologi. Semarang: Universitas Negeri Semarang.

Susanto A. (2013). Teori belajar dan pembelajaran di sekolah dasar. Jakarta:

Prenadamedia group.
Wena M. (2013). Strategi pembelajaran inovatif kontemporer. Jakarta: Bumi Aksara.

Yunita R, Ratna L, Eti MB. (2015). Minat belajar siswa kelas viii terhadap mata pelajaran ipa di $\mathrm{mts} p \mathrm{p}$ hasanatul barokah tambusai timur tahun pembelajaran 2014/2015. Jurnal Mahasiswa Prodi Biologi UPP. On line at www.medianeliti.com. 